UCRL --4459

DE86 002577

\title{
EFFECT OF A DENSITY GRADIENT ON TAYLOR INSTABILITY
}

\author{
R. LeLevier \\ G.J. Lasher \\ F. Bjorklund
}

February 21, 1955



manufacturer, or otherwise does not necessarily constitute or mendation, or favoring by the United States Government or any agency thereof The views and opinions of authors expressed herein do not necessarily state or reflect those of the United States Government or any agency thereof 


\section{DISCLAIMER}

This report was prepared as an account of work sponsored by an agency of the United States Government. Neither the United States Government nor any agency Thereof, nor any of their employees, makes any warranty, express or implied, or assumes any legal liability or responsibility for the accuracy, completeness, or usefulness of any information, apparatus, product, or process disclosed, or represents that its use would not infringe privately owned rights. Reference herein to any specific commercial product, process, or service by trade name, trademark, manufacturer, or otherwise does not necessarily constitute or imply its endorsement, recommendation, or favoring by the United States Government or any agency thereof. The views and opinions of authors expressed herein do not necessarily state or reflect those of the United States Government or any agency thereof. 


\section{DISCLAIMER}

Portions of this document may be illegible in electronic image products. Images are produced from the best available original document. 
UCRL-4459

\section{UNIVERSIT Y OF CALIFORNIA \\ Lawrence Radiation Laboratory}

Livermore, California

Contract No. W-7405-eng-48

\section{EFFECT OF A DENSITY GRADIENT ON TAYLOR INSTABILITY \\ R. LeLevier, G. J. Lasher, F. Bjorklund}

February 21,1955 
EFFECT OF A DENSIT Y GRADIENT ON TAYLOR INSTABILITY

R. LeLevier, G. Lasher, F. Bjorklund

University of California Radiation Laboratory

Livermore Site

February 21, 1955

\begin{abstract}
Taylor's derivation of the instability of an accelerated surface of density discontinuity is extended to the case in which the density has a smooth transition.
\end{abstract}




\title{
EFFECT OF A DENSITY GRADIENT ON TAYLOR INSTABILITY
}

\author{
R. Lelevier. G. Lasher, F. Bjorklund \\ University of California Radiation Laboratory \\ Livermore Site
}

February 21,1955

The model considered is an infinite incompressible fluid subjected to an acceleration, $g$, in the $y$ direction. (1) The initial density is of the form

(1) $\rho_{1}-\frac{1}{2} \delta \rho \mathrm{e}^{-\mathrm{Ky}}, \mathrm{y}>0$

(2) $\rho_{2}+\frac{1}{2} \delta \rho \mathrm{e}^{\mathrm{Ky}}, \mathrm{y}<0$

(3) where $\delta p=\rho_{1}-\rho_{2}>0$

An initial perturbation of the form $\cos \mathrm{kx}$ will be considered in the region of the $y=0$ plane. The amplitude of the perturbation is assumed small compared to its wave length. Let $y=\eta(x, t)$ be the equation of the surface of density $\frac{1}{2}\left(\rho_{1}+\rho_{2}\right)$.

The linearized hydrodynamical equations which will be used are:

(4) $u_{x}+v_{y}=0$

(5) $\rho u_{t}+P_{x}=0$

(6) $\rho v_{t}+P_{y}-\rho g=0$

Take a velocity potential

(7) $\phi=e^{-k y} \cos k x f(t) \quad y>0$

$$
=e^{k y} \cos k x f(t) \quad y<0
$$

(8) To first order $\rho=\rho_{t}=0+\int \dot{\rho}_{t}=0 d t$

$$
\text { where } \dot{p}_{\mathrm{t}}=0 \cong-\mathrm{v} \rho_{\mathrm{y}}
$$


Integrating (6) from $L$ to $\eta$ and from $-L$ to $\eta$ where $\cdot L$ is some constant large compared to $\frac{1}{\mathrm{~K}}$ and $\frac{1}{\mathrm{k}}$, dropping terms of second order and higher in $f$, and $\dot{f}$, and equating the two expressions for $P_{y}=\eta^{\prime}$ one obtains

$$
\begin{aligned}
& \dot{f}(t) \cos (k x)\left(\rho_{1}+\rho_{2}\right)-g \frac{k K}{k+K} \quad \delta \rho \cos k x \int_{f}(t) d t+\text { const. }=0 \\
& \text { or }\left(\rho_{1}+\rho_{2}\right) \ddot{f}-g \frac{k K}{k+K} \quad \delta \rho f=0
\end{aligned}
$$

The rate of growth is thus exponential with a growth constant

$$
\frac{1}{t}=\sqrt{\frac{g k K \delta \rho}{(k+K)\left(\rho_{1}+\rho_{2}\right)}}
$$

At the short wave length limit $k \rightarrow \infty t \rightarrow$ const. rather than diverging as in the case of a discontinuity in density. (2)

\section{REFERENCES}

(1) This is an extension of the work done by G. I. Taylor, Proc. Roy. Soc., A201, p 192, (1950).

See also R. H. Pennington and R. Bellman, PNJ-LA-1.

(2) The possibility of this behavior was suggested to us by E. Teller.

\section{NOTICE}

"This report was prepared as an account of work sponsored by the United States Government. Neither the United States nor the United States Department of Energy, nor any of their employees, nor any of their contractors, subcontractors, or their employees, makes any warranty, express or implied, or assumes any legal liability or responsibility for the accuracy, completeness or usefulness of any information, apparatus, product or process disclosed, or represents that its use would not infringe privately-owned rights."

Reference to a company or product names does not imply approval or recommendation of the product by the University of California or the U.S. Department of Energy to the exclusion of others that may be suitable. 